ISSN (print): 1698-6180. ISSN (online): 1886-7995

www.ucm.es/info/estratig/journal.htm

Journal of Iberian Geology 38 (2) 2012: 449-465

http://dx.doi.org/10.5209/rev_JIGE.2012.v38.n2.40468

\title{
Comparison of benthic foraminifera and geochemical proxies in shelf deposits from the Upper Jurassic of the Prebetic (southern Spain)
}

\author{
Comparación entre foraminíferos bentónicos e indicadores geoquímicos en \\ depósitos de plataforma del Jurásico superior del Prebético (Sur de España)
}

\author{
M. Reolid ${ }^{1 *}$, F. Martínez-Ruiz ${ }^{2}$ \\ ${ }^{1}$ Departamento de Geología, Universidad de Jaén, Campus Las Lagunillas sn, 23071 Jaén, Spain. \\ ${ }_{2}^{2}$ Instituto Andaluz de Ciencias de la Tierra (CSIC-UGR), Avda. de Las Palmeras 4, 18100 Armilla, Granada, Spain.
}

*Corresponding autor: mreolid@ujaen.es

Received: 22/01/2012 / Accepted: 02/09/2012

\begin{abstract}
Comparison of the stratigraphic distribution of major and trace elements, used as proxies for palaeoproductivity and redox conditions, and benthic foraminifera from Oxfordian shelf deposits of the External Prebetic (Betic Cordillera, South Spain) allows us to recognise two sedimentary cycles, both characterised by initial enhanced productivity and decreasing oxygen availability in the seabottom, and a subsequent decreasing productivity with a recovering in oxygenation during the second half of each cycle. Dysoxic conditions appear to coincide with maximums in marine surface productivity, thus suggesting that oxygen depletion may be linked to greater consumption rather than restricted circulation. The boundary between the two cycles is characterised by low contents of redox-sensitive elements and lower TOC content and $\mathrm{Sr} / \mathrm{Al}, \mathrm{P} / \mathrm{Ti}, \mathrm{Ca} / \mathrm{Al}$ and $\mathrm{Ba} / \mathrm{Al}$ ratios, indicating well oxygenated sea-bottom, lower productivity and lower organic matter accumulation. The geochemical proxies have also revealed as a valuable tool for interpreting the stratigraphic fluctuations of benthic foraminiferal assemblages, as well as for evaluating the palaeoecology of the main genera. Spirillina is adversely influenced by oxygen depletion independently of food availability. Ophthalmidium presents very good correspondence with palaeoproductivity fluctuations, and tolerated low oxygen levels in the sediment-water interface. Reophax was an opportunist that proliferated after adverse conditions when oxygenation and food availability were limiting factors. The variability in the microhabitat depth inside the sediment of Reophax favoured adaptation to adverse conditions. Lenticulina shows behaviour similar to Reophax. Finally, Ammobaculites shows a low degree of relation with the palaeoproductivity proxies, and is intolerant with respect to low oxygen values in shallow infaunal microhabitats.
\end{abstract}

Keywords:foraminifera, geochemistry, redox conditions, palaeoproductivity, marl-limestone rhythmite, Oxfordian-Kimmeridgian 


\section{Resumen}

La comparación de la distribución estratigráfica de indicadores geoquímicos de paleoproductividad y condiciones redox junto con foraminíferos bentónicos en los depósitos de plataforma del Oxfordiense (Jurásico superior) del Prebético Externo (Cordillera Bética, SE España) permite reconocer dos ciclos caracterizados por un incremento inicial de la productividad y una disminución de la oxigenación en el fondo y una posterior disminución en productividad y aumento de la oxigenación. Las condiciones disóxicas coinciden con máximos en la productividad marina superficial sugiriendo que la disminución de la oxigenación pudo estar relacionada con un mayor consumo relacionado con la oxidación de la materia orgánica más que por una circulación restringida. El límite entre ambos ciclos se caracteriza por valores bajos de elementos indicadores de condiciones reductoras, carbono orgánico total y las relaciones $\mathrm{Sr} / \mathrm{Al}, \mathrm{P} / \mathrm{Ti}, \mathrm{Ca} / \mathrm{Al}$ y Ba/Al, indicando buena oxigenación del fondo marino, baja productividad y baja acumulación de materia orgánica. Los indicadores geoquímicos han mostrado ser una valiosa herramienta para interpretar fluctuaciones estratigráficas en las asociaciones de foraminíferos bentónicos, así como para evaluar la paleoecología de los principales géneros de foraminíferos. Spirillina es sensible a las disminuciones en el grado de oxigenación independientemente de la disponibilidad de alimento. Ophthalmidium presenta muy buena correspondencia con las fluctuaciones en paleoproductividad y toleró bajos niveles de oxigenación en la interfase agua-sedimento. Reophax fue un organismo oportunista que proliferó bajo condiciones adversas cuando la oxigenación o el alimento fueron factores limitantes. La variabilidad en la profundidad del microhabitat dentro del sedimento de Reophax favoreció su adaptación a condiciones adversas. Lenticulina muestra un comportamiento similar a Reophax. Finalmente, Ammobaculites muestra una escasa relación con las variaciones de los indicadores de paleoproductividad, pero se muestra intolerante con respecto a valores bajos de oxigenación en los microhábitats infaunales someros.

Palabras clave: foraminífero, geoquímica, condiciones redox, paleoproductividad, ritmita margoso-calcárea, OxfordienseKimmeridgiense

\section{Introduction}

Studies of benthic foraminiferal assemblages from the Upper Jurassic have proven to be useful tools for interpreting palaeoenvironmental features such as oxygenation degree, sedimentation rate and nutrient availability (e.g., Nagy, 1992; Nagy et al., 1995; Jenkins, 2000; Bouhamdi et al., 2001; Reolid et al., 2008a, b; 2010; Nagy et al., 2009). The benthic taxa are particularly important as direct bioindicators of physico-chemical parameters at the sea-bottom, and indirectly of the water column features (e.g., Van der Zwaan et al., 1990; 1999; Loubere, 1996; Lüning et al., 1998; Gooday and Hughes, 2002; Hanagata, 2004; Mello e Sousa et al., 2006; Mojtahid et al., 2006).

In addition, geochemical proxies for reconstructing palaeoredox conditions and palaeoproductivity also constitute a valuable tool for testing palaeoenvironmental interpretations based on fossil benthic foraminiferal assemblages, as well as for evaluating palaeoecology assigned to different genera. Analysis of the redox conditions in the water column and in the sea-bottom is based on redox-sensitive trace elements $(\mathrm{Co}, \mathrm{Cu}, \mathrm{Ni}, \mathrm{Cr}, \mathrm{V}, \mathrm{Zn}$, $\mathrm{Mo}, \mathrm{Pb}, \mathrm{Cd}, \mathrm{U}$, and $\mathrm{Th}$ ), which tend to be less soluble under reducing conditions, resulting in synsedimentary enrichments under oxygen-depleted conditions (Wignall and Myers, 1988; Calvert and Pedersen, 1993; Jones and Manning, 1994; Powell et al., 2003; Siebert et al., 2003; Jiménez-Espejo et al., 2007; Gallego-Torres et al., 2007; 2010; Yilmaz et al., 2010). Some redox-sensitive metals $(\mathrm{Ni}, \mathrm{Cu}$, and $\mathrm{Zn}$ ) are delivered to the sediment in associa- tion with organic matter. These redox-sensitive elements tend to coprecipitate with sulfides (mainly pyrite) and are not usually remobilised during diagenesis in the absence of postdepositional replacement of oxydizing agents (Tribovillard et al., 2006).

Concerning palaeoproductivity rates, different geochemical proxies are commonly employed in the interpretation of relative fluctuations in productivity. Thus, Latimer and Filippelli (2001) and Robertson and Filippelli (2008) use the P/Ti ratio, while Sun et al. (2008) also study the $\mathrm{Ca} / \mathrm{Al}$ and $\mathrm{Sr} / \mathrm{Al}$ ratios. The most extensively used proxy for palaeoproductivity reconstructions, however, is Ba enrichment in marine sediments, since it has been demonstrated that $\mathrm{Ba}$ is a reliable indicator for variations in biological productivity when derived from authigenic marine barite originated in the water column (e.g., Dehairs et al., 1987; Bishop, 1988; Dymond et al., 1992; Van Os et al., 1994; Francois et al., 1995; Paytan et al., 1996; Martínez-Ruiz et al., 2000; Turgeon and Brumsack, 2006; Gallego-Torres et al., 2007). Barium proxies are considered as reliable indicators of productivity when postdepositional alteration does not compromise barite preservation. In general, barite is relatively resistant to diagenetic alteration after burial in sediments where pore waters are sulfate rich, and can therefore be considered a consistent proxy (e.g., Rutsch et al., 1995; McManus et al., 1999).

The main source of $\mathrm{P}$ to the sediment is the phytoplankton necromass that accumulates on the sediment-water interface together with vertebrate remains. However, the input of phosphorous from continents into marine basins 
can be important (Filippelli, 2008). The $\mathrm{P} / \mathrm{Ti}$ ratio reflects excessive phosphorous delivery to the sea-bottom not supported by terrigenous components. For this reason, an increase in the P/Ti ratio implies higher phosphorous sedimentation to the sea-bottom from biological processes (Latimer and Filippelli, 2001; Flores et al., 2005; Sen et al., 2008; Reolid et al., 2012). Usually the $\mathrm{P}$ is released as $\mathrm{PO}_{4}^{3-}$ from decaying organic matter during bacterial degradation below the sediment water interface. However, $\mathrm{P}$ cycling is very efficient, and it has been estimated that only $1 \%$ of organic phosphorous is trapped in sediments (Benitez-Nelson, 2000). As mentioned above, the relative contribution of the biogenic versus terrigenous components to the sediment can also be inferred through $\mathrm{Ca} / \mathrm{Al}$ and $\mathrm{Sr} / \mathrm{Al}$ ratios that are controlled mainly by fluctuations in the production and dissolution of the carbonate fraction and dilution by terrigenous inputs; yet $\mathrm{Ca} / \mathrm{Al}$ and $\mathrm{Sr} /$ $\mathrm{Al}$ are less commonly used as proxies of palaeoproductivity (Sun et al., 2008; Reolid et al., 2012).

The total organic carbon (TOC) has also been employed as an indirect palaeoproductivity proxy (e.g., Calvert and Fontugne, 2001; Gupta and Kawahata, 2006; Plewa et al., 2006; Wenbo et al., 2008), although enhanced TOC contents may result from low bottomwater ventilation and oxygen depletion, and are not necessarily related to high surface productivity. Total organic carbon (TOC) in the sedimentary rocks records only a fraction of the total biological palaeoproductivity in the water column (phytoplankton) and sea-bottom (phytobenthos). The TOC is the result of the organic matter that escapes from the generally efficient recycling system, which operates in the water column and at the seabottom. According to Tribovillard et al. (2006), despite complications attributable to efficient organic recycling, export productivity, delivery to the sediment-water interface and final burial, the TOC is generally proportional to surface-water productivity and constitutes a useful palaeoproductivity proxy.

Integrating these geochemical proxies for productivity and oxygen conditions, the present study compares the stratigraphic distribution of selected benthic foraminifera with such proxies throughout the Middle OxfordianLowermost Kimmeridgian in a marl-limestone rhythmite from the Prebetic (southern Spain). The focus of this work is on:

1.- Reconstruction of the fluctuations of nutrient fluxes, carbon fixation in the form of organic matter and palaeoproductivity variations during the Late Oxfordian-Early Kimmeridgian. This is an important period in that it represents the flooding of the shallow oolitic shelf of the south Iberian palaeomargin with the installation of hemipelagic facies.
2.- Reconstruction of oxygenation conditions in the sea-bottom.

3.- Evaluation of the role of productivity versus oxygenation degree in the stratigraphic distribution of selected benthic foraminifera (Spirillina, Ophthalmidium, Lenticulina, Reophax, and Ammobaculites). The selected foraminifera are the most abundant foraminifera in the studied assemblages and in mid-shelf to slope environments of the Upper Jurassic epicontinental platforms.

4.- Comparison of geochemical proxies of palaeoproductivity and palaeoredox conditions with previous interpretations about the behaviour of selected benthic foraminifera with respect to nutrient and oxygen availability.

\section{Studied section}

The rocks studied correspond to the External Prebetic, the northern part of the Betic Cordillera that represented the deposits of a mid- to outer-shelf environment during the Late Jurassic. The section studied is the RiogazasChorro-Esponjas (RGCHSP), located in the western part of the Sierra de Cazorla (southern Spain, Fig. 1). The outcrop is situated along the forest road from La Iruela to the Spring of the Guadalquivir River (coordinates $3^{\circ} 0$ ' $25^{\prime \prime} \mathrm{W}$ $\left.35^{\circ} 52^{\prime} 55^{\prime \prime} \mathrm{N}\right)$. This section is constituted by a $22-\mathrm{m}$-thick marl-limestone rhythmite belonging to the Lorente Formation, and comprises three upward-thickening sequences and a sponge-microbialite buildup (Fig. 2). The microfacies are mainly packstone-wackestone with peloids and bioclasts. The mineralogy of the marly levels is characterised by calcite, quartz and clay minerals (illite, kaolinite, smectites, illite-smectite interstratified and glauconite). The limestone beds present trace fossils of Chondrites and, less abundantly, Planolites. The age of the section ranges from Bifurcatus (Late Oxfordian) to Planula Zone (Earliest Kimmeridgian) (Olóriz et al., 1999).

The boundary between Middle Jurassic oolitic limestones and the Oxfordian deposits is a discontinuity. The upper boundary of the studied succession consists of an omission surface with abundant cephalopod remains and ferruginous oxides, which limits with a thick marly interval of the Platynota Zone (Lower Kimmeridgian).

More recent palaeontological studies in the RGCHSP section describe ammonoid biostratigraphy (Olóriz et al., 1999), taphonomy of the foraminifera and macroinvertebrate assemblages (Olóriz et al., 2002; 2003b; Reolid, 2008) and composition of foraminiferal assemblages (Olóriz et al., 2003a). These studies suggest a transgressive-regressive cycle for the studied interval, with a maximum flooding zone in the Bifurcatus Zone related to the top of the sponge-microbialite buildup. 


\section{Methods}

The analysis of microfacies and the foraminiferal assemblages was done on 63 thin sections from 21 sampling levels using a petrographic microscope (three thin sections per sampling level). Other 40 thin sections from distinct 36 sampling levels have been used only for checking potential fluctuations of microfacies and foraminiferal assemblages (Fig. 2). More than 2900 foraminifera were analysed. The material studied is deposited in the Matías Reolid Foraminiferal Collection, Universidad de Jaén, Spain (MRfC-UJA). Part of the material studied was analysed previously from palaeoecologic and taphonomic point of view (Olóriz et al., 2003a; Reolid, 2008). Mainly what is new in this study we analyse the stratigraphic distribution of selected foraminiferal assemblages from the paleoecological standpoint comparing with geochemical proxies.

Mineralogical composition was determined by x-ray diffraction in a Philips PV1710 powder diffractometer, using an $X^{\prime}$ Celerator detector from the Department of Mineralogy and Petrology of the Universidad de Granada. Additionally, morphological and compositional studies on selected samples focused on marine barite were performed by means of field emission scanning electron microscopy (FESEM), LEO (Carl Zeiss) model GEMINI-1530, at the Centro de Instrumentación Científica (CIC) of the Universidad de of Granada.

The geochemical analysis was carried out on 16 samples from marly levels. Whole-rock analyses of major elements of the crust were done using X-ray fluorescence (XRF) in a Philips PW 1040/10 spectrometer. Trace elements were analysed using an inductively coupled plasma-mass spectrometer (ICP-MS), the Perkin Elmer Sciex-Elan 5000, again at the CIC (University of Granada). The instrumental error was $\pm 2 \%$ and $\pm 5 \%$ for elemental concentrations of $50 \mathrm{ppm}$ and $5 \mathrm{ppm}$, respectively (Bea 1996).

Total organic carbon was analysed by leaching in the laboratories of SGS Canada Inc (Ontario). Total carbon (C) contents were measured as $\mathrm{mg}$ and calculated as percent-

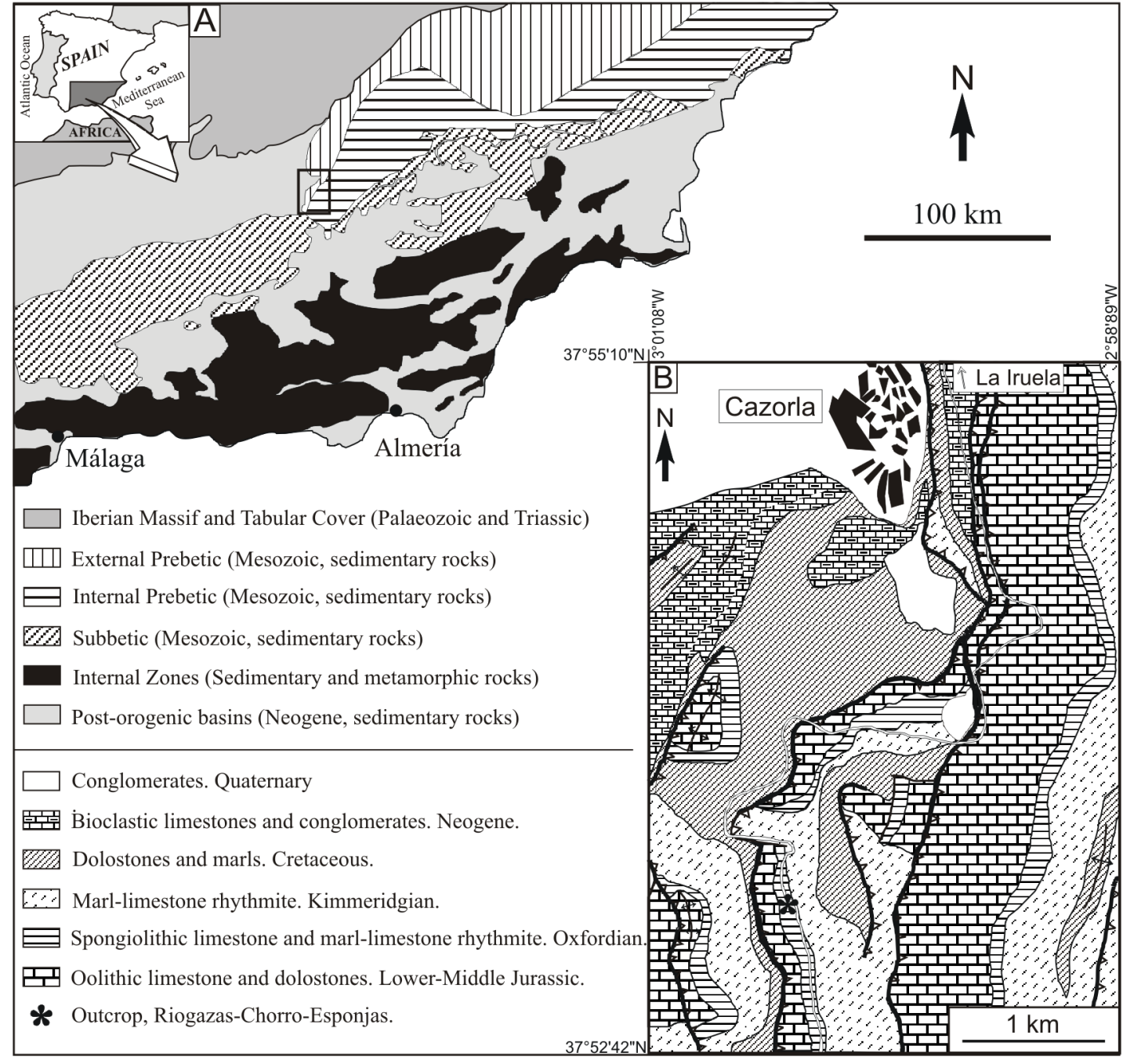

Fig. 1.- Geological setting of the studied outcrop in the External Prebetic (Betic Cordillera, SE Spain).

Fig. 1.- Localización geológica del perfil estudiado en el Prebético Externo (Cordillera Bética, SE España). 
ages of the sample's weight. Precision and accuracy of the method are approximately $0.01 \%$ and $92 \%$, respectively.

To make possible comparisons of trace-element proportions in samples with variable carbonate and clays contents, it is usual to normalize trace-element concentrations to aluminum content (Calvert and Pedersen, 1993). The study of palaeoproductivity was carried out applying a set of proxies constituted by $\mathrm{Ba} / \mathrm{Al}, \mathrm{Sr} / \mathrm{Al}, \mathrm{Ca} / \mathrm{Al}, \mathrm{P} / \mathrm{Ti}$, and TOC. For the analysis of palaeo-oxygenation, diverse redox proxies evaluating the relative increase of redox sensitive elements such as $\mathrm{Co} / \mathrm{Al}, \mathrm{Cu} / \mathrm{Al}, \mathrm{Cr} / \mathrm{Al}, \mathrm{V} / \mathrm{Al}, \mathrm{Ni} / \mathrm{Al}$, $\mathrm{Mo} / \mathrm{Al}$, and $\mathrm{Pb} / \mathrm{Al}$ were applied throughout the section.

\section{Results}

\subsection{Foraminiferal assemblages}

Previous taphonomic analysis on the studied foraminiferal assemblages indicates their autochthony to para-autochthony, and the scarcity of potentially allochthonous specimens (Reolid, 2008), that is crucial for supporting the interpretations focused on the composition of foraminiferal assemblages. The mean composition of the foraminiferal assemblage in this section is dominated by vagile benthic forms (89\%) with minor values of sessile forms $(7 \%)$ and planktic foraminifera (4\%). The $\alpha$-diversity index of the assemblage is 2.8 (with 29 genera), and no significant stratigraphic fluctuations are registered.

Among the vagile benthic forms, the two main groups correspond to the Order Spirillinina (39\%, mainly Spirillina and less commonly Conicospirillina) and the Order Textulariina (38\%, mainly Reophax and Ammobaculites, with less abundant Ammodiscus, Redmondoides, Ammomarginulina, and Haplophragmoides). The secondary components correspond to the orders Lagenina (13\%, Lenticulina, Dentalina, Nodosaria, Marginulina, Astacolus, and Planularia), Miliolina (9\%, Ophthalmidium) and Robertinina (1\% Epistomina). Bearing in mind the relevance of the distinct foraminifera and the previous palaeoecological interpretations, this study focuses on the selected genera Spirillina, Ophthalmidium, Reophax, Ammobaculites, and Lenticulina.

\subsection{Stratigraphic distribution of the geochemical prox- ies and foraminifera}

On the basis of the stratigraphic distribution of the geochemical parameters (Figs. 3 and 4), two main cycles can be differentiated. The main fluctuations in the proportions of distinct foraminifera (Fig. 5) can be correlated to these cycles.
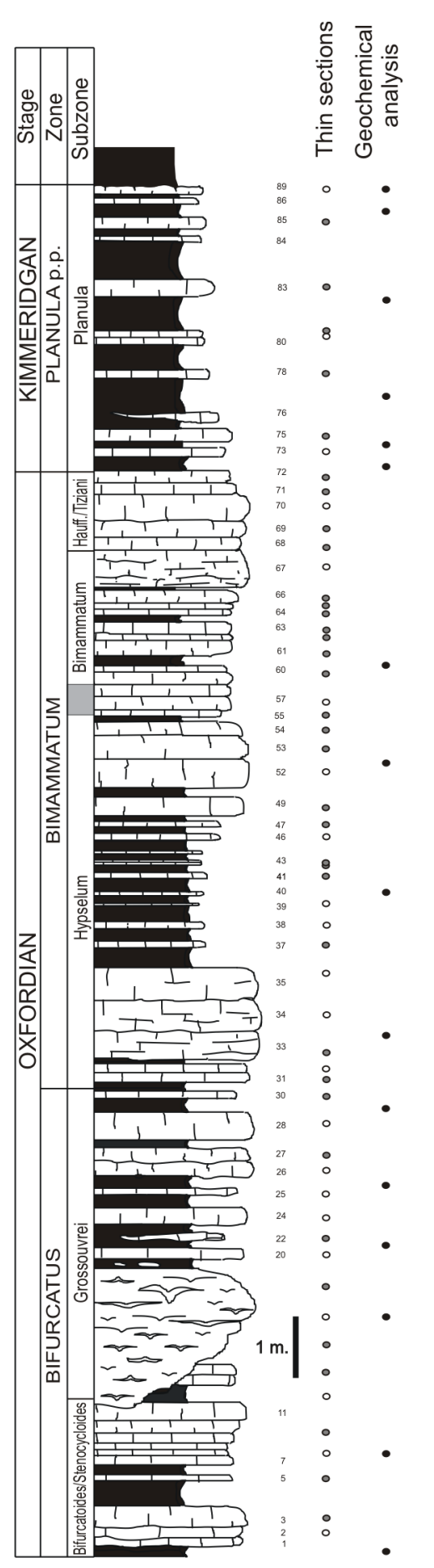

$\begin{array}{llll} & & & \\ { }_{80} & 8 & \\ { }_{78} & \circ & \\ & & - \\ { }_{76} & & \\ 75 & \circ & \bullet \\ 73 & 0 & \end{array}$

$$
\begin{array}{ll}
\circ & \\
0 & \\
0 & \\
0 & \\
0 & \\
8 & \\
8 & \\
0 & \\
0 & 0
\end{array}
$$
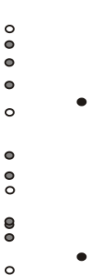

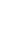

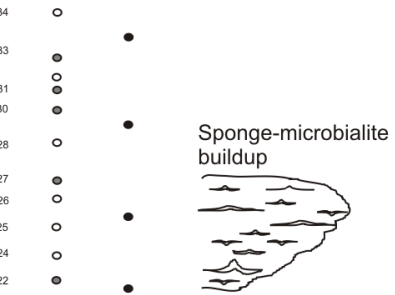

Fig. 2.- Riogazas-Chorro-Esponjas section (RGCHSP) with ammonoid biozones. Location of the samples is indicated: white circles for levels with three thin sections used in the foraminiferal analysis; grey circles for complementary thin sections (number of foraminifera not representative); black circles for samples of bulk geochemical analyses.

Fig. 2.- Perfil de Riogazas-Chorro-Esponjas (RGCHSP) con biozonas de ammonites. La localización de las muestras está indicada: círculos blancos para niveles con al menos tres láminas delgadas utilizadas para el análisis de foraminíferos; círculos grises para láminas delgadas complementarias (número de foraminíferos no representativo); círculos negros para análisis geoquímicos en muestra total. 


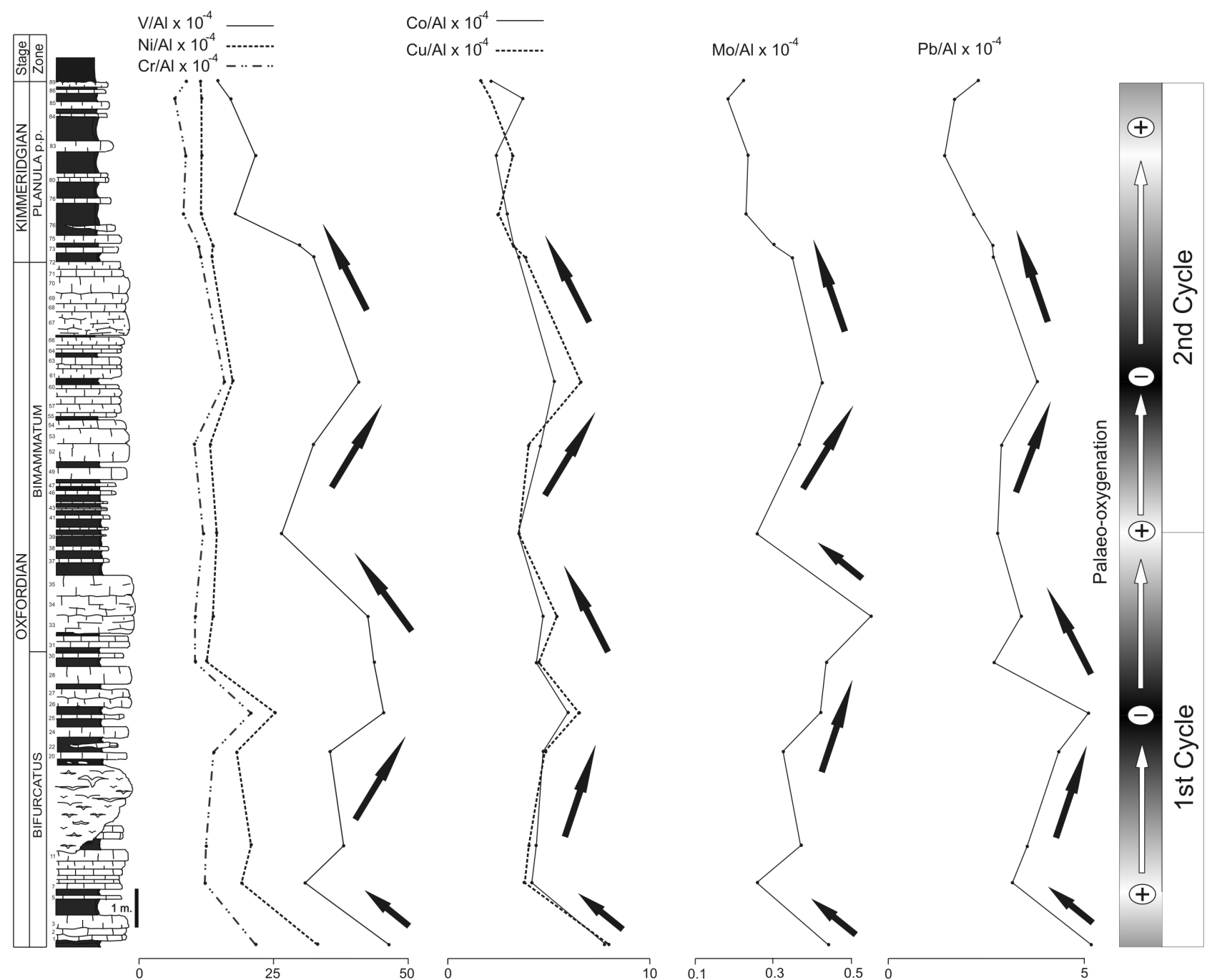

Fig. 3.- Stratigraphic distribution of geochemical proxies indicating redox conditions during deposition of the Late Oxfordian-Earliest Kimmeridgian sediments of the Riogazas-Chorro-Esponjas section.

Fig. 3.- Distribución estratigráfica de indicadores geoquímicos de condiciones redox durante el depósito de los sedimentos del Oxfordiense tardío al Kimmeridgiense temprano de la sección de Riogazas-Chorro-Esponjas.

\section{First cycle.}

As a general trend, the section begins with increasing values in the redox proxies reflected in the $\mathrm{Co} / \mathrm{Al}, \mathrm{Cu} / \mathrm{Al}$, $\mathrm{Cr} / \mathrm{Al}, \mathrm{V} / \mathrm{Al}, \mathrm{Ni} / \mathrm{Al}, \mathrm{Zn} / \mathrm{Al}$, and $\mathrm{Pb} / \mathrm{Al}$ ratios (Fig. 3). In the case of the $\mathrm{Mo} / \mathrm{Al}$ ratio, the maximum presents a lag with respect to the other proxies. The point of inflexion of this cycle is located in the level RGCHSP-25, just $1.5 \mathrm{~m}$ below the Bifurcatus/Bimammatum zone boundary; after this bed, the values of the redox proxies $(\mathrm{Co} / \mathrm{Al}, \mathrm{Cu} / \mathrm{Al}$, $\mathrm{Cr} / \mathrm{Al}, \mathrm{V} / \mathrm{Al}, \mathrm{Ni} / \mathrm{Al}, \mathrm{Zn} / \mathrm{Al}, \mathrm{Pb} / \mathrm{Al}$, and $\mathrm{Mo} / \mathrm{Al}$ ) decrease. The top of this cycle is located at level RGCHSP-40, which is the boundary between the biohorizons of Epipeltoceras semimammatum and Epipeltoceras berrense (Hypselum Subzone) of the Bimammatum Zone (Olóriz et al., 1999).

A similar trend can be observed with respect to the palaeoproductivity proxies, with increasing values of $\mathrm{Sr} / \mathrm{Al}$,
$\mathrm{P} / \mathrm{Ti}, \mathrm{Ca} / \mathrm{Al}$ and $\mathrm{TOC}$, and maximum values close to the Bifurcatus/Bimammatum zone boundary (Fig. 4). The highest value registered in TOC is $2.9 \%$. A very particular case is the $\mathrm{Ba} / \mathrm{Al}$ ratio, with increasing values but a maximum located $90 \mathrm{~cm}$ after the Bifurcatus/Bimammatum zone boundary, in coincidence with the $\mathrm{Mo} / \mathrm{Al}$ ratio. The cycle is completed with a decrease of the palaeoproductivity proxies that ends at the top of the cycle (level RGCHSP-40). Marine barite is not very abundant in these carbonate-rich samples, yet some barite grains were identified in samples from the sponge-microbialite buildup; this would support a potential $\mathrm{Ba}$ enrichment derived from marine barite accumulation, and thus enhanced productivity.

The benthic foraminifera show very distinct trends (Fig. 5). Ophthalmidium has a good correspondence with the fluctuations of TOC values as well as with some redox proxies, whereas proportions and size of Spirillina 

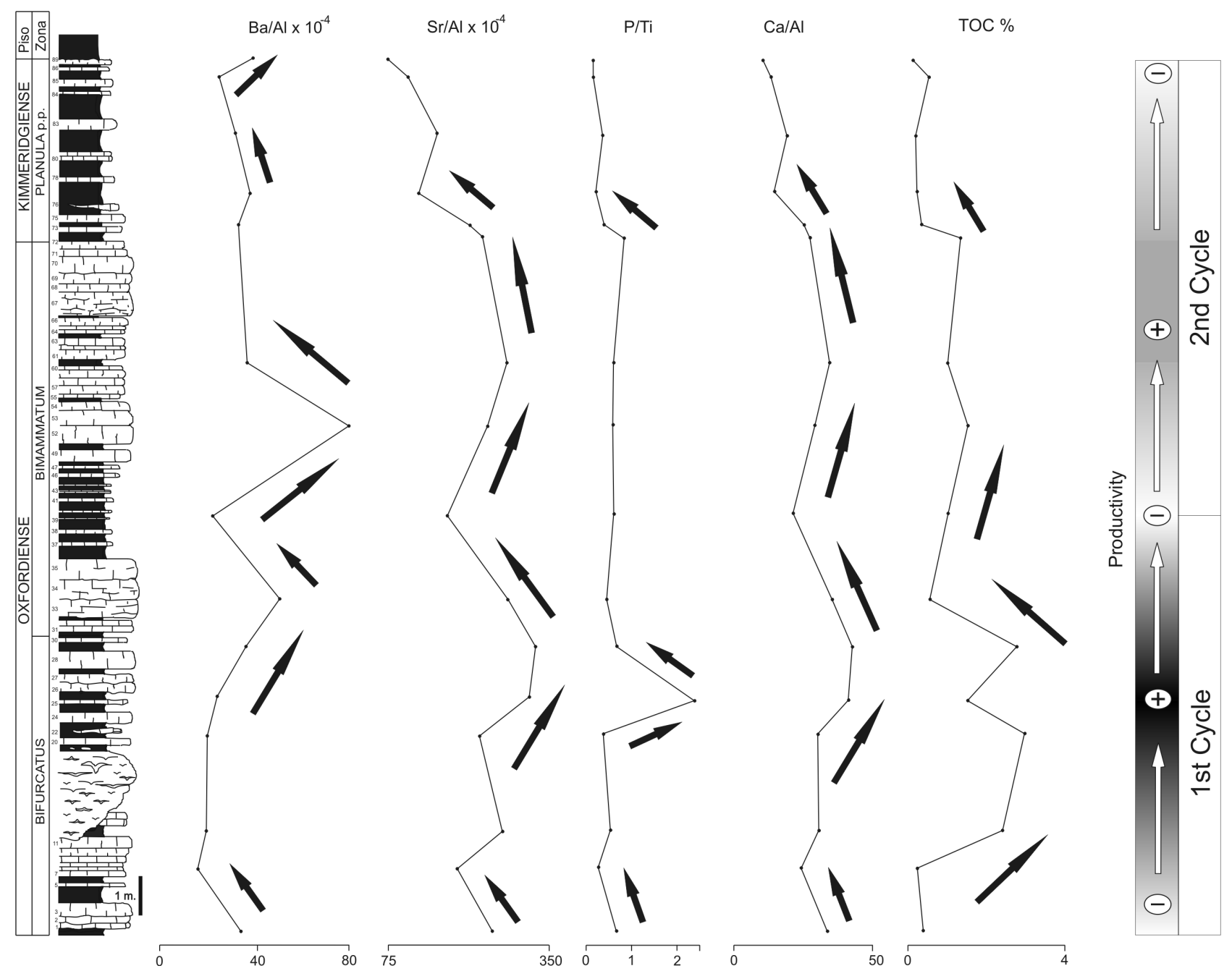

Fig. 4.- Stratigraphic distribution of geochemical proxies indicating productivity conditions during the Late Oxfordian-Earliest Kimmeridgian of the Riogazas-Chorro-Esponjas section.

Fig. 4.- Distribución estratigráfica de indicadores geoquímicos de productividad durante el depósito de los sedimentos del Oxfordiense tardío al Kimmeridgiense temprano de la sección de Riogazas-Chorro-Esponjas.

correlate with the $\mathrm{Ba} / \mathrm{Al}$ ratio. In the maximum of $\mathrm{TOC}$ values Ophthalmidium reaches $22 \%$ of the foraminiferal assemblage with the largest mean-size for this genus $(284$ $\mu \mathrm{m})$. Especially interesting is the distribution of Ammobaculites, with a general trend parallel to the palaeoproductivity proxies, but presenting an interruption with a local minimum that coincides with the highest values of the redox proxies. In the distribution of Lenticulina and Reophax highlights a maximum coincident with the highest values of the redox proxies. Reophax presents the largest specimens (339 $\mu \mathrm{m}$ mean-size) with the maximum of redox and palaeoproductivity proxies.

\section{Second cycle}

The level RGCHSP-40, where the boundary between the biohorizons of Epipeltoceras semimammatum and Epipeltoceras berrense (Hypselum Subzone) of the Bimammatum Zone is located, constitutes the base of the second cycle and the change in trend for most of the geochemical proxies. This boundary is inside a marly-rich interval. The trends of this cycle are less clear than in the first cycle.

The second cycle begins with increasing values in the redox proxies $\mathrm{Co} / \mathrm{Al}, \mathrm{Cu} / \mathrm{Al}, \mathrm{Cr} / \mathrm{Al}, \mathrm{Mo} / \mathrm{Al}, \mathrm{V} / \mathrm{Al}, \mathrm{Ni} / \mathrm{Al}$, $\mathrm{Zn} / \mathrm{Al}$, and $\mathrm{Pb} / \mathrm{Al}$ ratios (Fig. 3). The maximum values are reached at the top of the level RGCHSP-60 (Bimammatum Subzone, Bimammatum Zone), after which bed the values of the redox proxies show a slight upwardly decreasing trend. The top of the Oxfordian (Bimammatum/Planula zone boundary, level RGCHSP-72) constitutes a sharp change with an accentuated diminution in the values of the redox proxies (mainly observed in $\mathrm{Zn}$ / $\mathrm{Al}, \mathrm{Ni} / \mathrm{Al}, \mathrm{Cr} / \mathrm{Al}$, and $\mathrm{Mo} / \mathrm{Al})$.

The palaeoproductivity proxies $(\mathrm{Sr} / \mathrm{Al}, \mathrm{Ca} / \mathrm{Al}$, and TOC) show increasing values in the first half of the cycle (Fig. 4). The maximum values are located in the level 
RGCHSP-60 (Sr/Al and $\mathrm{Ca} / \mathrm{Al})$, and in the Oxfordian/ Kimmeridgian boundary at level RGCHSP-72 (P/Ti and $\mathrm{TOC})$. As in the first cycle, the $\mathrm{Ba} / \mathrm{Al}$ ratio points to different positions for the maximum value. The entrance to the Planula Zone is characterised by a strong decrease in $\mathrm{Sr} / \mathrm{Al}, \mathrm{P} / \mathrm{Ti}, \mathrm{Ca} / \mathrm{Al}$, and TOC (Fig. 4).

As occurs in the first cycle, Ophthalmidium shows a good correspondence with the fluctuations of TOC values, as does Spirillina with the $\mathrm{Ba} / \mathrm{Al}$ ratio. There are no significant changes in the shell size of Ophthalmidium and Spirillina in this interval. Proportions of Reophax in the foraminiferal assemblage have two local maximums (Fig. 5), one at the base of the cycle (when redox and palaeoproductivity proxies have low values) and other close to the Oxfordian/Kimmeridgian boundary (where $\mathrm{P} / \mathrm{Ti}$ and TOC have their highest values in the cycle). At the beginning of the Planula Zone (Kimmeridgian), Ophthalmidium, Spirillina and Reophax diminish, whereas Ammobaculites and Lenticulina increase, although the values are recovered in the omission surface at the top of the section.

\section{Discussion}

The depth within the sediment of the infaunal microhabitat of benthic foraminifera is known to be related to the sedimentation rate and the position of the redox boundary, the latter depending on the organic matter content and oxygenation degree of the sediment. Jorissen et al. (1995) and Van der Zwaan et al. (1999) highlighted food availability and oxygenation as limiting factors in the distribution of foraminifera in infaunal microhabitats (TROX-model).

The organic matter that foraminifera consume directly or indirectly as nutrients in a shelf environment can have different origins: a) autochthonous, mainly proceeding from primary photosynthetic production; or b) exported from shallower or emerged areas in relation to detritic inputs. Primary photosynthetic production can take place in the sea-bottom by phytobenthos, and in the water column by phytoplankton. The primary production is scarce under the lower limit of the shallow euphotic zone. Accordingly, primary production —and therefore nutrient availability for foraminifera - is higher in shallow environments of the shelf where planktic and benthic primary production coexist. In carbonate platforms, these areas usually coincide with the maximum carbonate production area (carbonate factory s. Schlager, 1993; Pomar and Ward, 1995; Homewood, 1996; among others) located in the inner-shelf. The External Prebetic has been interpreted as distal areas of the platform, corresponding to a mid- shelf (in a ramp model), with low primary production and organic matter input related to inputs from emerged and more proximal areas (inner-shelf) (Olóriz et al., 2003b; 2006; Reolid et al., 2008b). The phytodetritus inputs represent one means of distribution of organic matter from a carbonate production area toward more distal areas.

Organic matter is an essential controlling factor for benthic foraminiferal assemblages, as both a direct and an indirect food resource: organic matter could be consumed directly by foraminifera and microbes, and the latter are also a food resource for foraminifera. The increase of phytodetritus in the sediment produces increasing biomass and activity of foraminifera that use labile components or microbial populations proliferating in relation to phytodetritic deposits (Thiel et al., 1990; Lochte, 1992; Gooday, 1996; Turley, 2000; Nomaki et al., 2005).

The position of the redox boundary in the sediment, that is, the range of the infaunal ecospace, controls the ecological structure of infaunal forms. An increase in organic matter content produces an increase in the metabolic activity of the microbiota, consuming the oxygen of the pore water. The position of the redox boundary under oligotrophic conditions may be some meters below the sediment-water interface, and thus below the zone of benthic activity (Kuhnt et al., 1996); whereas under conditions of very high organic input, the redox boundary layer may be close to the sediment-water interface (unfavourable to infaunal forms). However, some agglutinated infaunal foraminifera from the Jurassic tolerated hypoxic conditions (Bernhard, 1986; Nagy, 1992; Tyszka, 1994; Nagy et al., 2010; Reolid et al., 2010). In addition, grain-size and sedimentation rate bear a direct impact on oxygenation of the infaunal microhabitats (Reolid et al., 2008b). A high sedimentation rate and fine grain-size (clay and silt) limit pore-water circulation and substrate oxygenation. Moreover, the relation between organic matter content and oxygenation degree of the sediment may be affected by external factors such as seawater mass stratifications with low oxygenation in the sea-bottom.

\subsection{Benthic foraminifera and palaeoproductivity proxies}

Micropalaeontological analyses previously performed on sedimentary rocks from Ardeche (SE France) and in the Prebetic (Betic Cordillera) by Bouhamdi et al. (2001), Olóriz et al. (2003a, b), and Reolid et al. (2008a) have concluded that the genus Spirillina serves as a good proxy of nutrient availability, usually related to high mesotrophic conditions. The availability of trophic resources when Spirillina presents high proportions in the foraminiferal assemblage may be the result of high pro- 

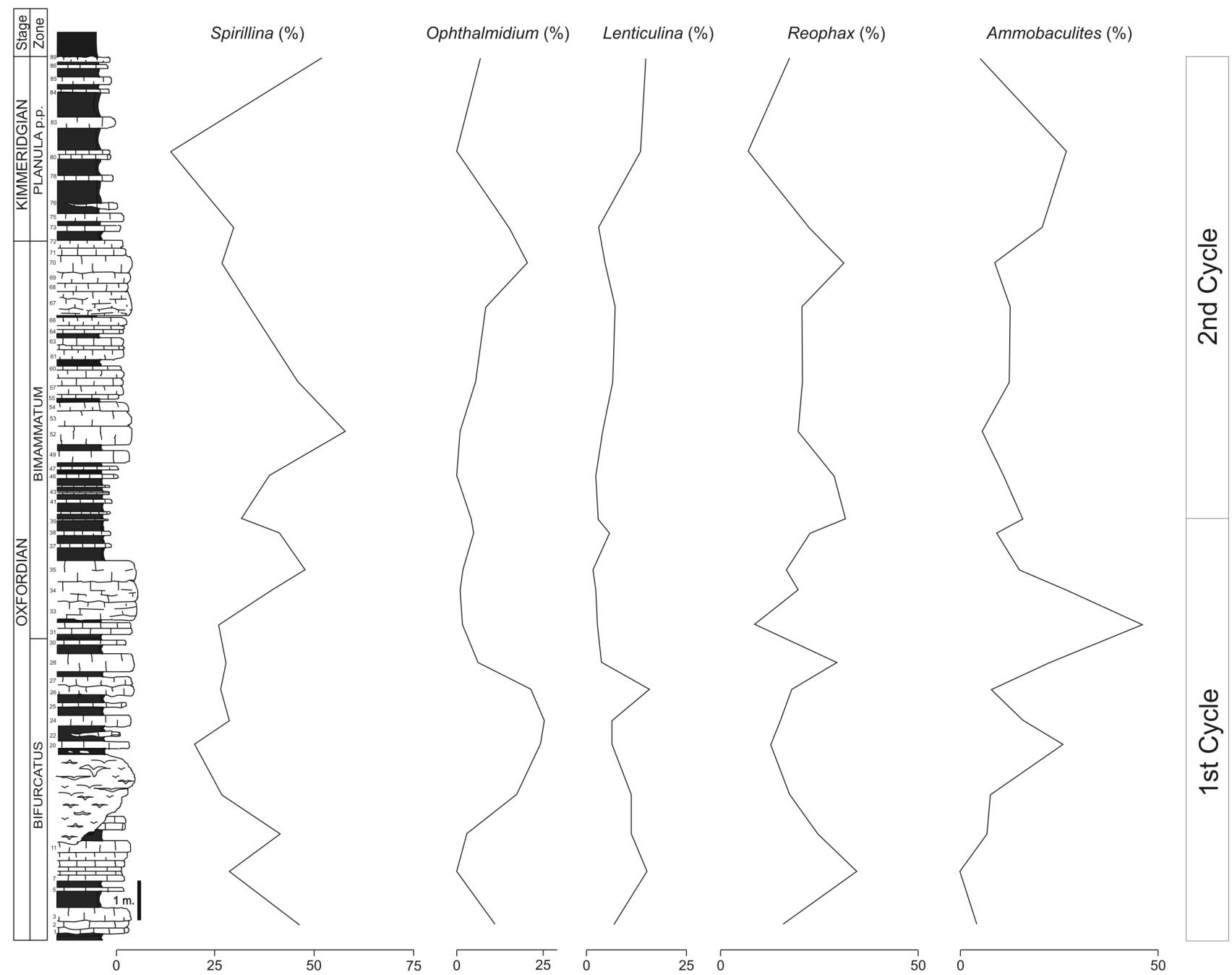

Fig. 5.- Stratigraphic distribution of selected fossil benthic foraminifera of the Upper Oxfordian-Lowermost Kimmeridgian from the studied section.

Fig. 5.- Distribución estratigráfica de foraminíferos bentónicos sésiles seleccionados del Oxfordiense superior-Kimmeridgiense temprano de la sección estudiada.

ductivity episodes at both the phytobenthos and the phytoplankton levels, given that Spirillina is an epifaunal or epiphytal form of grazing phytodetritus (Tyszka, 1994).

The highest values recorded in the proportions of Spirillina correspond to the middle part of the section and coincide with maximums in the $\mathrm{Ba} / \mathrm{Al}$ ratio (Figs. 4 and 5). In relation to the first maximum, we observed an increase in the test size, which would be congruent with the interpretation of Spirillina in relation to nutrient availability and primary production. However, Spirillina does not have a good correlation with the other palaeoproductivity proxies (P/Ti, Sr/Al, Ca/Al, and TOC). This contradicts the expected trends. As epifaunal grazers, spirillinids would indicate dense bacterial populations related to organic carbon particles in the flocculent layer, probably phytodetritus, and to macroscopic algae (Morris, 1982; Kitazato, 1988; Nagy, 1992; Tyszka, 2001; among oth- ers). Therefore, a close proportional relation of Spirillina and TOC could be expected. Yet the influence of oxygen availability on Spirillina, not described in the literature to date, might be considered a limiting factor. Additional factors such as seawater temperature may control the relative abundance of Spirillina (Gómez et al., 2009).

Ophthalmidium is an epifaunal porcelaneous foraminifera (miliolids) with active deposit-feeder, herbivore and detritivore trophic behaviour (Tyszka, 1994). In modern faunas, miliolids are characteristic of the intertidal zone and inner-shelf (e.g. Saraswati, 2002; Murray, 2006; Gualancañay, 2007; Villanueva-Gulmerans and Canudo, 2008), and they increase in abundance according to food resources when oxygen is not a limiting factor (Halfar and Ingle, 2003). However, Oxfordian species of Ophthalmidium reveal a preference for relatively deep shelf conditions (Olóriz et al., 2003a; Reolid et al., 2008a, b). 
In the section studied, the relative abundance and size of Ophthalmidium present very good correspondence with the palaeoproductivity proxies, mainly with TOC, a finding congruent with the link of this genus with food availability (Figs. 4, 5 and 6).

Reophax is a uniserial genus with variable habitat depth, from shallow to deep infaunal, interpreted as a detritivore and bacterial scavenger (Nagy, 1992; Tyszka, 1994). Reophax flourish in the two cycles described when the palaeoproductivity proxies present extreme values $(\mathrm{Sr} /$ $\mathrm{Al}, \mathrm{Ca} / \mathrm{Al}$, and TOC). Proportions and size of Reophax increase when palaeoproductivity proxies reach the highest values (RGCHSP-25 and RGCHSP-70), and relative abundance (but not size) increases when the palaeoproductivity proxies show the lowest values (RGCHSP-9 and RGCHSP-40). In Mesozoic deposits, Reophax has been described as an opportunist (Jenkins, 2000; Galeotti et al., 2002; Reolid et al., 2008b). This is compatible with the high proportions of Reophax coincident with the record of low values in the palaeoproductivity proxies, considering food availability as a main limiting factor. Increased relative abundance of Reophax when palaeoproductivity proxies record high values would indicate some influence of the other main controlling factor, oxygen availability (discussed in the next subchapter).

The cosmopolitan genus Lenticulina, a biconvex and planispiral calcitic foraminifera, presents a microhabitat similar to that of Reophax, ranging from epifaunal to deep infaunal, with active deposit-feeder and grazing omnivore feeding strategies. Tyszka (1994) interpreted the test shape of Lenticulina as favourable to vertical mobility in the sediment and opportunistic behaviour. The trends of the relative abundances of Lenticulina in the first cycle are similar to the fluctuations of Reophax, the other opportunist, with a potentially deep infaunal habitat.

Finally, Ammobaculites, an elongated form, which agglutinates coarse grains in the studied samples (probably corresponding to A. coprolitiformis), presents an apparently low relation with the palaeoproductivity proxies. In the first cycle, Ammobaculites increase with the palaeoproductivity proxies, then decrease just with the highest values in $\mathrm{P} /$ Ti ratio and high values in the other palaeoproductivity proxies. The size of Ammobaculites in the first cycle goes from 380 to $>600 \mu \mathrm{m}$ according to increasing values of the palaeoproductivity proxies. In the second cycle, Ammobaculites present low proportions in the foraminiferal assemblage, and a slight diminution when palaeoproductivity proxies increase. In Kimmeridgian sediments of southern England, Jenkins (2000) found a negative correlation between infaunal Ammobaculites and the TOC. Reolid et al. (2008a, b) report higher values of Ammobaculites in the Internal Prebetic (outer-shelf to upper slope with oligotrophic conditions) than in the External Prebetic (mid-shelf with high-mesotrophic conditions), in opposite way of the palaeogeographic distribution of Reophax and trophic resources.

\subsection{Benthic foraminifera and redox proxies}

The marl-limestone rhythmite of the Oxfordian from the External Prebetic has been interpreted as deposited under high-mesotrophic conditions with a redox boundary shallower than in more distal settings of the epicontinental shelf of the Internal Prebetic (Reolid et al., 2008a, b). This was interpreted based on the infaunal tiering structure of the foraminiferal assemblage, and is congruent with the record of Chondrites. This trace fossil is a feeding system of unknown organisms related to infaunal deposit-feeding, which may have been able to live in dysaerobic conditions as a chemosymbiont (Seilacher, 1990; $\mathrm{Fu}, 1991)$. However, the first geochemical analysis done in these deposits suggests higher TOC values and oxygen depletion than previously thought.

Spirillina presents low values in those intervals having higher values for the redox proxies $(\mathrm{Co} / \mathrm{Al}, \mathrm{Cu} / \mathrm{Al}, \mathrm{Cr} /$ $\mathrm{Al}, \mathrm{V} / \mathrm{Al}$, and $\mathrm{Ni} / \mathrm{Al}$ ), thus indicating depleted oxygen, in spite of the correspondence of high values for some palaeoproductivity proxies $(\mathrm{Sr} / \mathrm{Al}, \mathrm{P} / \mathrm{Ti}, \mathrm{Ca} / \mathrm{Al}$, and $\mathrm{TOC}$; Figs. 3-5). This distribution is not the expected trend if the proposals of Bouhamdi et al. (2001) and Olóriz et al. (2003b) are taken into account, where Spirillina is interpreted as indicative of nutrient availability related to primary photosynthetic production. These previous works did not consider the effect of oxygen availability on Spirillina. However, the palaeogeographic distribution of Spirillina in the Prebetic shelf system is congruent with increasing proportions (according to the positive gradient of availability) of trophic resources, with dominance of Spirillina in the foraminiferal assemblages of the mid-shelf environments featuring high-mesotrophic conditions (Olóriz et al., 2006; Reolid et al., 2008a, b). Therefore, studying trends of Spirillina proportions in this section of the External Prebetic point to an adverse influence of oxygen depletion on Spirillina regardless of food availability.

In the section studied, the proportions and size of $O p h-$ thalmidium present a very good correlation with the increasing values of the redox proxies and TOC, mainly in the first cycle (Figs. 3 and 5), suggesting that Ophthalmidium tolerated low oxygen levels in the sedimentwater interface. This observation contrasts with the more classic interpretation for miliolids, reportedly intolerant 
to oxygen deficient conditions due to their imperforated shells, which impede efficient gas exchange with the water (e.g. Boudchiche and Ruget, 1993). In modern faunas, miliolids increase in abundance along with trophic resources, when oxygen is not a limiting factor (Halfar and Ingle, 2003). In the context of Jurassic species of Ophthalmidium, a preference for well oxygenated environments has been put forth (Gordon, 1970; Barnard et al., 1981; Boudchiche, 1986; Gregory, 1990; Hughes, 2004). According to the results expounded above, Ophthalmidium tolerate relatively low oxygen conditions and may have been at some advantage in the epifaunal microhabitat when competing with Spirillina.

Reophax increase in the two cycles described near the levels at which the redox and palaeoproductivity proxies respectively reach their highest values (RGCHSP-25 and RGCHSP-70), and lowest values (RGCHSP-9 and RGCHSP-40, Figs. 3-5). In recent examples, Van der Zwaan et al., (1999) indicate differences in the microhabitat depth of Reophax related to fluctuations of the redox boundary. Under normal marine conditions, Kaminski et al., (1995) observed that the genus can survive at lowered oxygen levels $(0.5 \mathrm{ml} / 1)$. Subsequently, the high values of Reophax following the maximums in $\mathrm{V} / \mathrm{Al}, \mathrm{Ni} / \mathrm{Al}, \mathrm{Co} / \mathrm{Al}$, $\mathrm{Cu} / \mathrm{Al}, \mathrm{Cr} / \mathrm{Al}$, and $\mathrm{Zn} / \mathrm{Al}$ would constitute the colonization and profusion of this opportunist after the episodes of oxygen depletion of each cycle. This means that $R e-$ ophax was an opportunist that proliferated after adverse conditions when oxygenation and food availability were limiting factors. Variability in the microhabitat depth favoured its adaptation to adverse conditions.

The fluctuating proportions of Ammobaculites in the foraminiferal assemblages bear no evident relation with redox and palaeoproductivity proxies, proving difficult to interpret. Only a clear diminution of Ammobaculites in the first cycle - at level RGCHSP-25 - can be related to maximums in $\mathrm{V} / \mathrm{Al}, \mathrm{Ni} / \mathrm{Al}, \mathrm{Co} / \mathrm{Al}, \mathrm{Cu} / \mathrm{Al} \mathrm{Cr} / \mathrm{Al}, \mathrm{Zn} / \mathrm{Al}$, P/Ti, and TOC (Figs. 3-5). Accordingly, Ammobaculites might be considered intolerant of low oxygen values in pore water in shallow infaunal microhabitats. According to Reolid et al. (2008b), Ammobaculites and Reophax have different palaeoecological requirements. Namely, agglutinated foraminifera from mid-shelf environments were dominated by Reophax, in turn favoured by finegrained sediment with high organic matter content and nutrients, with changing redox boundary according to fluctuating nutrient inputs; and elsewise, Ammobaculites dominated among the agglutinated foraminifera from outer-shelf to upper slope settings with coarse-grained sediments and low organic matter content, favouring a deeper and comparatively stable redox level.
The proportions of Lenticulina show only one significant local maximum in the first cycle, in the sense that it correlates well with high values of $\mathrm{V} / \mathrm{Al}, \mathrm{Ni} / \mathrm{Al}, \mathrm{Co} / \mathrm{Al}$, $\mathrm{Cu} / \mathrm{Al}$, and $\mathrm{Cr} / \mathrm{Al}$ ratios (Figs. 3 and 5). Tyszka (1994) interpreted the vertical mobility of the infaunal microhabitat and the r-selected behaviour (Nini et al., 1995) as advantageous for recolonisation after redox fluctuations inside soft- and soupygrounds.

\subsection{Interpretation of stratigraphic geochemical fluctuations}

According to the redox and palaeoproductivity proxies, two sedimentary cycles can be differentiated (Figs. 3-6). Both cycles are characterised by increasing-decreasing upward trends in the values of the redox and palaeoproductivity proxies. Therefore, both cycles comprise initially increasing productivity together with decreasing oxygen availability in the sea-bottom, reaching dysoxic conditions, and the subsequent reduction in productivity and recovery of oxygenation in the sea-bottom during the second half of the cycles.

Dysoxic conditions appear to coincide with maximums in marine productivity, thus suggesting that oxygen depletion may be linked to greater consumption rather than restricted circulation. Such productivity fluctuations could be related to marine surface fertility as well as phytobenthic productivity in more proximal settings, with exportation to outer settings, which may have overwhelmed oxygenation rates and resulted in organic matter accumulation in the sediment.

The first cycle is the most intense: it shows high values in the redox proxies and $\mathrm{P} / \mathrm{Ti}$ in coincidence with the maximum flooding interpreted by Olóriz et al. (2002; 2003a, b) and Reolid (2008). The dysoxic conditions reached in this cycle control local maximums in the proportions of Reophax and Lenticulina (Fig. 6), both of them opportunist and potentially deep infaunal forms. According to Sjoerdsma and Van der Zwaan (1992), the opportunistic behaviour of some foraminifera is related to nutrient input, whereby a nutrient increase favours proliferation of r-type strategists.

The limiting factor of the assemblage was the porewater oxygen availability affecting other infaunal forms such as Ammobaculites. Unexpectedly high values of Ophthalmidium indicate its tolerance of dysoxic conditions. Since the maximum values of redox proxies coincide with maximum productivity, or a slight offset, reduced oxygen concentrations are constrained to TOC-rich levels. The increased palaeoproductivity within this cycle is related almost exclusively to marine surface fertility, 


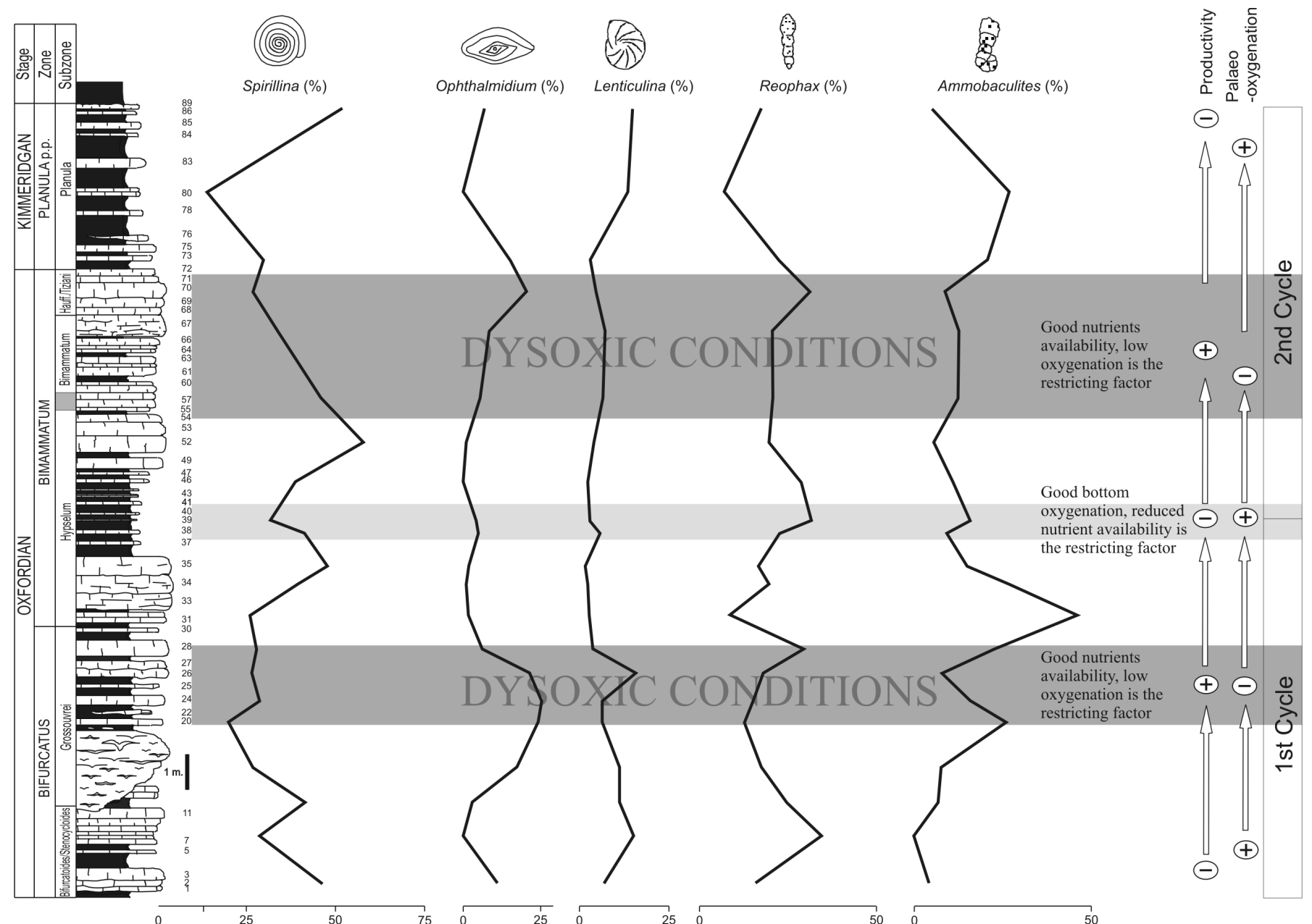

Fig. 6.- Interpretation of palaeoproductivity and palaeo-oxygenation conditions during the Bifurcatus (Late Oxfordian) - Planula (Earliest Kimmeridgian) zones compared with distribution of proportions of selected foraminifera.

Fig. 6.- Interpretación de las condiciones de paleoproductividad y paleoxigenación durante las zonas Bifurcatus (Oxfordiense tardío) -Planula (Kimmeridgiense temprano) comparada con la distribución de las proporciones de foraminíferos seleccionados.

while phytobenthic productivity in a more proximal carbonate factory with exportation of organic matter (phytodetritus and carbonate) to outer settings would be minor, given the context of maximum flooding (Olóriz et al., 2002; Reolid, 2008). The high values of redox and palaeoproductivity proxies of the studied section are very well correlated by ammonoid biostratigraphy with condensed lithofacies from outer-shelf to upper slope environments of the Internal Prebetic (Olóriz et al., 2002; 2004).

Hence, oxygenation increases while organic matter accumulation decreases, as does the proliferation of Ammobaculites and Spirillina, while Ophthalmidium and opportunists Reophax and Lenticulina are also diminished. However, progress in the reduction in food availability (mainly phytodetritus) produces a new diminution of $\mathrm{Am}$ mobaculites and Spirillina at the top of the cycle. The level RGCHSP-40 constitutes the boundary between the two cycles, and is characterised by low values of redox and palaeoproductivity proxies, indicating good oxygenation in the sea-bottom, comparatively low productivity, and lower organic matter accumulation (Fig. 6). The tiering of the foraminifera is predominantly determined by oxygen and nutrient availability (Tyszka, 1994; Jorissen et al., 1995; Van der Zwaan et al., 1999; Ernst and Van der Zwaan, 2004), so that food availability was the limiting factor in the boundary between the cycles described. Reophax was favoured in these adverse conditions, probably occupying higher tiers in the infaunal microhabitat at the expense of Ammobaculites.

The second cycle presents the same trends in redox and palaeoproductivity proxies, but the values are lower than in the first cycle (Fig. 6). Benthic foraminifera reflect the same response to higher values of organic matter in the sediment and progressive oxygen depletion, with local increases of Reophax and Ophthalmidium, and low values in Spirillina and Ammobaculites. 
The Bimammatum/Planula zone boundary evidences an important change in the lithofacies as well as in the geochemical proxies. The sediment was more terrigenous during the Planula Zone, with a dominance of marly intervals over calcareous beds. Some of the palaeoproductivity proxies ( $\mathrm{Sr} / \mathrm{Al}, \mathrm{P} / \mathrm{Ti}, \mathrm{Ca} / \mathrm{Al}$, and $\mathrm{TOC}$ ) show a sharp drop at this boundary. The $\mathrm{Cr} / \mathrm{Al}, \mathrm{Mo} / \mathrm{Al}$, and $\mathrm{Ni} / \mathrm{Al}$ ratios present the same accentuated decrease.

Later approaches interpreted the Planula Zone deposits in the South Iberian Palaeomargin as marked by the interactions between tectonics and eustasy (Marques et al., 1991; Olóriz et al., 2002; 2004; Reolid, 2008; RodríguezTovar et al., 2010), and the increase of siliciclastics as a consequence of reactivated topography in the source area (see also Aurell et al., 2003 for NE Iberia; and compatibility with carbonate production models in Pittet et al., 2000 for SE Iberia, and Allenbach, 2002 for the Oxfordian in the Swiss Jura). Analogous situations affecting Upper Oxfordian deposits were later reported with regard to the evolution of the central North Atlantic and the Western Tethyan basins (e.g., Goldhammer, 1998; Leinfelder and Wilson, 1998; Allenbach, 2001; 2002; Bádenas and Aurell, 2001; Salas et al., 2001).

In palaeoecological terms, increasing terrigenous as well as decreasing trophic resources (related to less productivity and export organic matter) are unfavourable for most benthic forms, except Ammobaculites and Lenticulina. The other foraminifera recover at the top of the section, which is interpreted as an omission surface (Olóriz et al., 2002).

The redox proxies and the other palaeoproductivity proxies for both cycles suggest that the TOC-rich intervals development were controlled by episodes of increased primary productivity, since the values of the redox proxies do not appear to be high enough to control the accumulation of organic matter in the sea-bottom. Reduced deepwater ventilation is improbable, but cannot be ruled out.

Despite the clarity of the general trends, there is a stratigraphic delay among the different proxies studied and the $\mathrm{Ba} / \mathrm{Al}$ ratio. Only the $\mathrm{Ba} / \mathrm{Al}$ ratio indicates high productivity values in levels other than those marked by other palaeoproductivity proxies $(\mathrm{Sr} / \mathrm{Al}, \mathrm{P} / \mathrm{Ti}, \mathrm{Ca} /$ $\mathrm{Al}$, and TOC), although the minimum at the boundary of the cycles coincides. The delay in the $\mathrm{Ba} / \mathrm{Al}$ ratio signal could be related to the redox conditions. According to Tribovillard et al. (2006), barium may be lost from oxygen-deprived deposits because they are solubilised under reducing conditions. However, as described previously, the values of the redox proxies are no more indicative of strong oxygen depletion than dysoxic conditions would be, so the reason for the lag of the $\mathrm{Ba} / \mathrm{Al}$ signal is not clear. Additionally, the presence of barite crystals identified by SEM in numerous levels comes to support the preservation of this mineral, and the fact that it was not remobilised by sulphate reduction.

The unexpectedly high values of TOC in the Bifurcatus Zone are probably related to local conditions in the Prebetic. Oxfordian deposits with high TOC values are rarely described in the literature. Callovian-Oxfordian TOC-rich deposits have been reported for the Late Callovian-Early Oxfordian (Price and Gröcke, 2002) and one record of marine black shales deposited from the Late Bathonian to the Volgian (Bausch et al., 1998). Other descriptions of Oxfordian organic-rich deposits come from Nepal (Gradstein et al., 1991) and Svalbard (Dypvik et al., 1991; Reolid et al., 2010). Therefore, the records of organic-rich Oxfordian sediments are rare, and appear to represent local to regional processes rather than a condition of the global oceans (Pearce et al., 2005).

\section{Conclusions}

The Oxfordian deposits of the External Prebetic have been recently interpreted as distal areas of the platform, corresponding to a mid-shelf with low primary production, where phytodetritus inputs represented the distribution of organic matter from a carbonate production area toward more distal areas. In this context, comparison of the stratigraphic distribution of benthic foraminifera and geochemical proxies for palaeoproductivity and redox conditions gives rise to the following conclusions:

-Two sedimentary cycles can be differentiated, characterised by increasing-decreasing upward trends in the values of the redox and palaeoproductivity proxies. Each cycle is constituted by an initial increasing productivity trend together with decreasing oxygen availability in the sea-bottom that reaches dysoxic conditions; and the subsequent reduction in productivity and recovery of oxygenation in the sea-bottom during the second half of the cycle.

-Dysoxic conditions appear to coincide with maxima in marine productivity, thus suggesting that oxygen depletion may be linked to greater consumption rather than restricted circulation. These productivity fluctuations could be largely related to marine surface fertility, and some with phytobenthic productivity in more proximal settings involving exportation to outer settings, which may have overwhelmed oxygenation rates and resulted in organic matter accumulation within the sediment.

-Since maximum values of redox proxies in the first cycle are reached coinciding with maximum productivity or a slight offset, reduced oxygen concentrations are con- 
strained to TOC-rich levels. The increased palaeoproductivity within this cycle is related almost exclusively with marine surface fertility, while phytobenthic productivity in more proximal carbonate factory with exportation of organic matter (phytodetritus and carbonate) toward outer settings would be a minor effect in view of the context of maximum flooding.

-The boundary between the two cycles is characterised by low values for redox and palaeoproductivity proxies, indicating a well oxygenated sea-bottom, lower productivity and lower organic matter accumulation. The second cycle presents the same trends in redox and palaeoproductivity proxies, yet values are lower than in the first cycle.

The geochemical proxies of study are shown to be a valuable tool for interpreting the stratigraphic fluctuations of benthic foraminiferal assemblages, as well as for evaluating the palaeoecology of the main genera. In this sense, we arrive at these main conclusions:

-Spirillina presents low values in the intervals with higher values of the redox proxies $(\mathrm{Co} / \mathrm{Al}, \mathrm{Cu} / \mathrm{Al}, \mathrm{Cr} / \mathrm{Al}$, $\mathrm{V} / \mathrm{Al}$, and $\mathrm{Ni} / \mathrm{Al}$ ), which would indicate depleted oxygen, in spite of its high values corresponding to some of the palaeoproductivity proxies $(\mathrm{Sr} / \mathrm{Al}, \mathrm{P} / \mathrm{Ti}, \mathrm{Ca} / \mathrm{Al}$, and TOC). The study of the trends of proportions of Spirillina in this section of the External Prebetic leads us to interpret an adverse influence of oxygen depletion on Spirilli$n a$, independently of food availability.

-Relative abundance and size of Ophthalmidium present very good correspondence with the palaeoproductivity proxies, and increasing values of the redox proxies and TOC. Accordingly, Ophthalmidium tolerated low oxygen levels in the sediment-water interface and was probably favoured in the epifaunal microhabitat when competing with Spirillina.

-Reophax was an opportunist that proliferated after adverse conditions when oxygenation and food availability were limiting factors. The variability in the microhabitat depth of Reophax favoured its adaptation to adverse conditions. Reophax flourished (1) when redox proxies were maxima constituting the colonisation and profusion of this opportunist after the episodes of oxygen depletion of each cycle, and (2) when the palaeoproductivity proxies show the lowest values, considering the food availability a main limiting factor. The trends of relative abundance of Lenticulina in the first cycle are similar to the fluctuations of Reophax, the other opportunist, with a potentially deep infaunal habitat.

-Ammobaculites presents an apparently low relation with the palaeoproductivity proxies, and it is intolerant of low oxygen values in pore water in shallow infaunal microhabitats.

\section{Acknowledgements}

This research has been supported by the projects RYC2009-04316 (Programa Ramón y Cajal), PO-RNM-3715 and the research group RNM-178. We express our cordial thanks to J. Reolid for helping in the preparation of samples. We are grateful to a native English speaker (Jean Louise Sanders) for reviewing the grammar. Also we would like to thank Dr. J. Smoleń and an anonymous reviewer, as well as the editor J. Martín-Chivelet, for reviewing and improving the manuscript.

\section{References}

Allenbach, R.P. (2001): Synsedimentary tectonics in an epicontinental sea: A new interpretation of the Oxfordian basins of northern Switzerland. Eclogae Geologicae Helvetiae, 94: 265-287.

Allenbach, R.P. (2002): The ups and downs of "Tectonic Quiescence"-recognizing differential subsidence in the epicontinental sea of the Oxfordian in the Swiss Jura Mountains. Sedimentary Geology, 150: 323-342.

Aurell, M., Robles, S., Bádenas, B., Rosales, I., Quesada, S., Meléndez, G., García-Ramos, J.C. (2003): Transgressive-regressive cycles and Jurassic palaeogeography of northeast Iberia. Sedimentary Geology, 162: 171-239. doi:10.1016/S0037-0738(03)00154-4

Bádenas, B., Aurell, M. (2001): Kimmeridgian palaeogeography and basin evolution of northeastern Iberia. Palaeogeography, $\mathrm{Pa}$ laeoclimatology, Palaeoecology, 168: 291-310.

Barnard, T., Cordey, W.G., Shipp, D.J. (1981): Foraminifera from the Oxford Clay (Callovian-Oxfordian of England). Revista Española de Micropaleontología, 13: 383-462.

Bausch, W.M., Birkenmajer, K., Grunenberg, T., Krajewski, K.P., Kutyba, J. (1998): Clay-mineralogy of Jurassic marine black-shales in Spitsbergen: a positive evidence for climate cooling during Oxfordian. Bulletin of the Polish Academy of Sciences, Earth Sciences, 46: 211-221.

Bea, F. (1996): Residence of REE, Y, Th and U in granites and crustal protoliths: implications for the chemistry of crustal melts. Journal of Petrology, 37: 521-532.

Benítez-Nelson, C.R. (2000): The biogeochemical cycling of phosphorus in marine systems. Earth-Science Reviews, 51: 109-135.

Bernhard, J.M. (1986): Characteristic assemblages and morphologies from anoxic organic rich deposits: Jurassic through Holocene. Journal of Foraminiferal Research, 16: 207-215.

Bishop, J.K.B. (1988): The barite-opal-organic carbon association in oceanic particulate matter. Nature, 332: 341-343.

Boudchiche, L. (1986): Etude micropaléontologique du Domerien, Toarcien et Bajocien du massif des Béni-Snassen orientaux (Maroc nord oriental). MSc Thesis Université Claude-Bernard Lyon-1,190 pp.

Boudchiche, L., Ruget, C. (1993): Une réponse morphologique à un probléme écologique: l'exemple des foraminiféres du Toarcien inférieur des Béni-Snassen (Maroc nord-oriental). Comptes Rendus Academie Sciences, Paris, 316: 815-821.

Bouhamdi, A., Gaillard, C., Ruget, C. (2001): Spirillines versus agglutinants: impact du flux organique et intérêt paléoenvironnemental (Oxfordien moyen du Sud-Est de la France). Geobios, 34: 267-277.

Calvert, S.E., Fontugne, M.R. (2001): On the late Pleistocene-Holocene sapropel record of climatic and oceanographic variability in the eastern Mediterranean. Paleoceanography, 16: 78-94. 
Calvert, S.E., and Pedersen, T.F. (1993): Geochemistry of recent oxic and anoxic marine sediments: Implications for the geological record. Marine Geology, 113: 67-88.

Dehairs, F., Lambert, C.E., Chesselet, R., Risler, N. (1987): The biological production of marine suspended barite and the barium cycle in the western Mediterranean Sea. Biogeochemistry, 4: 119-139.

Dymond, J., Suess, E., Lyle, M. (1992): Barium in deep-sea sediment: a geochemical proxy for palaeoproductivity. Paleoceanography, 7: 163-181.

Dypvik, H., Nagy, J., Eikeland, T.A., Backer-Owe, K., Johansen, H. (1991): Depositional conditions of the Bathonian to Hauterivian Janusfjellet Subgroup, Spitsbergen. Sedimentary Geology, 72: $55-78$.

Ernst, S., Van der Zwaan, B. (2004): Effects of experimentally induced raised levels of organic flux and oxygen depletion on a continental slope benthic foraminiferal community. Deep-Sea Research Part I-Oceanographic Research Papers, 51: 1709-1739. doi:10.1016/j. dsr.2004.06.003.

Filippelli, G.M. (2008): The global phosphorous cycle: past, present, and future. Elements, 4: 89-95. doi:10.2113/GSELEMENTS.4.5.89

Flores, J.A., Sierro, F.J., Filippelli, G.M., Barcena, M.A., Pérez-Folgado, M., Vázquez, A., Utrilla, R. (2005): Surface water dynamics and phytoplankton communities during deposition of cyclic late Messinian sapropel sequences in the western Mediterranean. Marine Micropaleontology, 56: 50-79. doi:10.1016/j.marmicro.2005.04.002

Francois, R., Honjo, S., Manganini, S.J., Ravizza, G.E. (1995): Biogenic barium fluxes to deep sea: implications for paleoproductivity reconstruction. Global Biogeochemical Cycles, 9: 289-303.

$\mathrm{Fu}$, S. (1991): Funktion, Verhalten und Einteilung fucoider und lophoctenoider Lebensspuren. Courier Forschungsinstitut Senckenberg, 135: 1-79.

Galeotti, S., Bellagamba, M., Kaminski, M.A., Montanari, A. (2002): Deep-sea benthic foraminiferal recolonisation following a volcanoclastic event in the lower Campanian of the Scaglia Rossa Formation (Umbria-Marche, central Italy). Marine Micropaleontology, 44: 57-76. doi:10.1016/S0377-8398(01)00037-8

Gallego-Torres, D., Martínez-Ruiz, F., De Lange, G.J., Jiménez-Espejo, F.J., Ortega-Huertas, M. (2010): Trace-elements derived paleoceanographic and paleoclimatic conditions for Pleistocene Eastern Mediterranean sapropels. Palaeogeography, Palaeoclimatology, Palaeoecology, 293: 78-89. doi:10.1016/j.palaeo.2010.05.001

Gallego-Torres, Martínez-Ruiz, F., Paytan, A., Jiménez-Espejo, F.J., Ortega-Huertas, M. (2007): Pliocene-Holocene evolution of depositional conditions in the eastern Mediterranean: Role of anoxia vs. productivity at time of sapropel deposition. Palaeogeography, Palaeoclimatology, Palaecoecology, 246: 424-439. doi: 10.1016/j. palaeo.2006.10.008

Goldhammer, R.K. (1998): Second-Order Accommodation Cycles and Points of "Stratigraphic Turnaround": Implications for HighResolution Sequence Stratigraphy and Facies Architecture of the Haynesville and Cotton Valley Lime "Pinnacle Reefs" of the East Texas Basin. West Texas Geological Bulletin, 37, 5-9.

Gómez, J.J., Canales, M.L., Ureta, S., Goy, A. (2009): Paleoclimatic and biotic changes during the Aalenian (Middle Jurassic) at the southern Laurasian Seaway (Basque Cantabrian Basin, northern Spain). Palaeogeography, Palaeoclimatology, Palaecoecology, 275: 14-27. doi:10.1016/j.palaeo.2009.01.009

Gooday, A. (1996): Epifaunal and shallow infaunal foraminiferal communities at three abyssal NE Atlantic sites subject to differing phytodetritus input regimes. Deep-Sea Research I, 9: 1395-1421.

Gooday, A., Hughes, J.A. (2002): Foraminifera associated with phytodetritus deposits at a bathyal site in the northern Rockall Trough (NE Atlantic): seasonal contrasts and a comparison of stained and dead assemblages. Marine Micropaleontology, 46: 83-110. doi:10.1016/ S0377-8398(02)00050-6

Gordon, W.A. (1970): Biogeography of Jurassic foraminifera. Geological Society of America Bulletin, 81: 1689-1704.

Gradstein, F.M., Gibbling, M.R., Sarti, M., Von Rad, U., Thurow, J.W., Ogg, J.G., Jansa, L.F., Kaminski, M.A., Westermann, G.E.G. (1991): Mesozoic Tethyan strata of Thakkola, Nepal, evidence for drift and breakup of Gondwana. Palaeogeography, Palaeoclimatology, Palaeoecology, 88: 193-218.

Gregory, F.J. (1990): Foraminiferal biostratigraphy and paleoecology across the Aalenian/Bajocian of the proposal basal stratotype at Bearreraig Bay, NE Skye (Scotland). Memorie descrittive della Carta Geologica d'Italia, 40: 257-268.

Gualancañay, E. (2007): Distribución zoogeográfica de los géneros Cibicides sp., y Quinqueloculina sp., (Foraminiferos) de la zona de turbulencia de Monteverde, Ecuador durante noviembre de 2007. Acta Oceanográfica del Pacífico, 14, 163-167.

Gupta, L.P., Kawahata, H. (2006): Downcore diagenetic changes in organic matter and implications for paleoproductivity estimates. Global and Planetary Change, 53: 122-136. doi:10.1016/J.gloplacha.2006.01.008

Halfar, J., Ingle, J.C. (2003): Modern warm-temperate and subtropical shallow-water benthic foraminifera of the southern Gulf of California, Mexico. Journal of Foraminiferal Research, 33: 309-329. doi: $10.2113 / 0330309$

Hanagata, S. (2004): Miocene foraminifera from the Niigata oil and gas field region, northeastern Japan. Grzybowski Foundation Special Publication, 8: 151-166.

Homewood, P.W. (1996): The carbonate feedback system: interaction between stratigraphic accomodation, ecological succession and the carbonate factory. Bulletin de la Societé Géologique de France, 167: 701-715.

Hughes, G.W. (2004): Middle to Upper Jurassic Saudi Arabian carbonate petroleum reservoirs: biostratigraphy, micropalaeontology and palaeoenvironments. GeoArabia, 9: 79-114.

Jenkins, C.D. (2000): The ecological significance of foraminifera in the Kimmeridgian of Southern England. Grzybowski Foundation Special Publication, 7: 167-178.

Jiménez-Espejo, F.J., Martínez-Ruiz, F., Sakamoto, T., Iijima, K., Gallego-Torres, D., Harada, N. (2007): Paleoenvironmental changes in western Mediterranean since the last glacial maximum: high resolution multiproxy record from the Algero-Balearic basin. Palaeogeography, Palaeoclimatology, Palaecoecology, 246: 292-306. doi:10.1016/j.palaeo.2006.10.005

Jones, B.A., Manning, D.A.C. (1994): Comparison of geochemical indices used for the interpretation of paleoredox conditions in ancient mudstones. Chemical Geology, 111: 111-129.

Jorissen, F.J., de Stigter, H.C., Widmark, J.G.V. (1995): A conceptual model explaining benthic foraminiferal microhabitats. Marine Micropaleontology, 26: 3-15.

Kaminski, M.A., Boersma, A., Tyszka, J., Holbourn, A. (1995): Response of deep-water agglutinated benthic foraminifera to dysoxic conditions in the California Borderland Basins. Grzybowski Foundation Special Publication, 3: 131-140.

Kitazato, H. (1988): Ecology of benthic foraminifera in the tidal zone of a rocky shore. Revue de Paléobiologie Special volumen 2: 815825.

Kuhnt, W., Moullade, M., Kaminski, M.A. (1996): Ecological structuring and evolution of deep sea agglutinated foraminifera - A review. Revue de Micropaléontologie, 39: 271-281.

Latimer, J.C., Filippelli, G.M. (2001): Terrigenous input and paleoproductivity in the Southern Ocean. Paleoceanography, 16: 627-643. doi:10.1029/2000PA000586 
Leinfelder, R.R., Wilson, R.C. (1998): Third-order sequences in an upper Jurassic rift-related second-order sequence, Central Lusitanan Basin, Portugal. In: De Gracianski, P.C., Hardenbol, J., Jacquin, T., Vail, P.R. (Eds.), Mesozoic and Cenozoic Sequence Stratigraphy of European Basins. SEPM Special Publication, 60: 507-525.

Lochte, K. (1992): Bacterial standing stock and consumption of organic carbon in the benthic boundary layer of the abyssal North Atlantic. In: Rowe, G.T. and Pariente, V. (Eds.). Deep-sea Food Chains and the Global Carbon Cycle, 1-10. Kluwer Academic Publishers, The Netherlands.

Loubere, P. (1996): The surface ocean productivity and bottom water oxygen signals in deep water benthic foraminiferal assemblages. Marine Micropaleontology, 28: 247-261.

Lüning, S., Marzouk, A.M., Kuss, J. (1998): The Paleocene of central east Sinai, Egypt: "sequence stratigraphy" in monotonous hemipelagites. Journal of Foraminiferal Research, 28: 19-39.

Marques, B., Olóriz, F., Rodríguez-Tovar, F.J. (1991): Interactions between tectonics and eustasy during the Upper Jurassic and lowermost Cretaceous. Examples from the south of Iberia. Bulletin de la Societé Géologique de France, 162: 1109-1124.

Martínez-Ruiz, F., Kastner, M., Paytan, A., Ortega-Huertas, M., Bernasconi, S.M., 2000, Geochemical evidence for enhanced productivity during S1 sapropel deposition in the eastern Mediterranean. Paleoceanography, v. 15, p. 200-209.

McManus, J., Berelson, W.M., Hammond, D.E., Klinkhammer, G.P. (1999): Barium cycling in the North Pacific: implications for the utility of $\mathrm{Ba}$ as a paleoproductivity and paleoalkalinity proxy. $\mathrm{Pa}$ leoceanography, 14: 53-61.

Mello e Sousa, S.H., Passos, R.F., Fukumoto, M., Silveira, I.C.A., Lopes-Figueira, R.C., Koutsoukos, E.A.M., Mahiquyes, M.M., Rezende, C.E. (2006): Mid-Lower bathyal benthic foraminifera of the Campos Basin, Southeastern Brazilian margin: biotopes and controlling ecological factors. Marine Micropaleontology, 61: 40-57. doi:10.1016/j.marmicro.2006.05.003

Mojtahid, M., Jorissen, F., Durrieu, J., Galgani, F., Howa, H., Redois, F., Camps, R. (2006): Benthic foraminifera as bio-indicators of drill cutting disposal in tropical east Atlantic outer shelf environments. Marine Micropaleontology, 61: 58-75. doi:10.1016/j.marmicro.2006.05.004

Morris, P.H. (1982): Distribution and paleoecology of Middle Jurassic foraminifera from the Lower Inferior Oolite of the Costwolds. $\mathrm{Pa}$ laeogeography, Palaeoecology, Palaeoclimatology, 37: 319-347.

Murray, J.W. (2006) Ecology and applications of benthic foraminifera. 426 p. Cambridge Univ. Press.

Nagy, J. (1992): Environmental significance of foraminiferal morphogroups in Jurassic North Sea deltas. Palaeogeography, $\mathrm{Pa}$ laeoecology, Palaeoclimatology, 95: 111-134. doi:10.1016/00310182(92)90168-5

Nagy, J., Gradstein, F.M., Kaminski, M.A., Holbourn, A.E. (1995): Foraminiferal morphogroups, paleoenvironments and new taxa from Jurassic to Cretaceous strata of Thakkhola, Nepal. Grzybowski Foundation Special Publication, 3: 181-209.

Nagy, J., Hess, S., Alve, E. (2010): Environmental significance of foraminiferal assemblages dominated by small-sized Ammodiscus and Trochammina in Triassic and Jurassic delta-influenced deposits. Earth-Science Reviews, 99: 31-49. doi:10.1016/j.earscirev.2010.02.002

Nagy, J., Reolid, M., Rodríguez-Tovar, F.J. (2009): Foraminiferal morphogroups in dysoxic shelf deposits from the Jurassic of Spitsbergen. Polar Research, 28: 114-121. doi:10.1111/j.17518369.2009.00112.x

Nini, C., Baldanza, A., Nocchi, M. (1995): Late Domerian-Toarcian calcareous nannofossil biostratigraphy, benthic foraminiferal as- semblages and their paleoenvironmental implications, Montebibico area (Spoleto, Central Italy). Revue de Paléobiologie, 14: 271-319.

Nomaki, H., Heintz, P., Nakatsuka, T., Shimanaga, M., Kitazato, H. (2005): Species-specific ingestion of organic carbon by deep-sea benthic foraminifera and meiobenthos. In situ tracer experiments. Limnology and Oceanography, 50: 134-146.

Olóriz, F., Reolid, M., Rodríguez-Tovar, F.J. (1999): Fine-resolution ammonite biostratigraphy at the Rio Gazas-Chorro II section in Sierra de Cazorla (Prebetic Zone, Jaén province, southern Spain). Profil, 16: 83-94.

Olóriz, F., Reolid, M., Rodríguez-Tovar, F.J. (2002): Fossil assemblages, lithofacies and taphofacies for interpreting depositional dynamics in epicontinental Oxfordian (Prebetic Zone, Betic Cordillera, southern Spain). Palaeogeography, Palaeoecology, Palaeoclimatology, 185: 53-75. doi:10.1016/S0031-0182(02)00277-8

Olóriz, F., Reolid, M., Rodríguez-Tovar, F.J. (2003a): Palaeogeographic and stratigraphic distribution of Mid-Late Oxfordian foraminiferal assemblages in the Prebetic Zone (Betic Cordillera, southern Spain). Geobios, 36: 733-747. doi:10.1016/j.geobios.2003.03.006

Olóriz, F., Reolid, M., Rodríguez-Tovar, F.J. (2003b): A Late Jurassic carbonate ramp colonized by sponges and benthic microbial communities (External Prebetic, Southern Spain). Palaios, 18: 528-545. doi:10.1669/0883-1351

Olóriz, F., Reolid, M., Rodríguez-Tovar, F.J. (2004): Microboring and taphonomy in Middle Oxfordian to lowermost Kimmeridgian (Upper Jurassic) from the Prebetic Zone (southern Iberia). Palaeogeography, Palaeoclimatology, Palaeoecology, 212: 181-197. doi:10.1016/j.palaeo.2004.05.022

Olóriz, F., Reolid, M., Rodríguez-Tovar, F.J. (2006): Approaching trophic structure in Late Jurassic neritic shelves: A western Tethys example from southern Iberia. Earth-Science Reviews, 79, 101139. doi:10.1016/j.earscirev.2006.06.005

Paytan, A., Kastner, M., Chávez, F.P. (1996): Glacial to interglacial fluctuations in productivity in the equatorial Pacific as indicated by marine barite. Science, 274: 1355-1357.

Pearce, C.R., Hesselbo, S.P., Coe, A.L. (2005): The mid-Oxfordian (Late Jurassic) positive carbon-isotope excursion recognised from fossil wood in the British Isles. Palaeogeography, $\mathrm{Pa}$ laeoclimatology, Palaeoecology, 221: 343-357. doi:10.1016/j. palaeo.2005.03.004

Pittet, B., Strasser, A., Mattioli, E. (2000): Depositional sequences in deep-shelf environments: a response to sea-level changes and shallow-platform carbonate productivity (Oxfordian, Germany and Spain). Journal of Sedimentary Research, 70: 392-407.

Plewa, K., Meggers, H., Kasten, S. (2006): Barium in sediments of northwest Africa: A tracer for palaeoproductivity or meltwater events? Paleoceanography, 21, PA2015. doi:10.1029/2005PA001136

Pomar, L., Ward, W.C. (1995): Sea-level changes, carbonate production and platform architecture: the Llucmajor Platform, Mallorca, Spain. In: B.U. Haq (Ed.). Sequence Stratigraphy and Depositional Response to Eustatic, Tectonic and Climatic Forcing, 87-112. Kluwer Academic Press, Dordrecht.

Powell, W.G., Johstone, P.A., Collom, C.J. (2003): Geochemical evidence for oxygenated bottom waters during deposition of fossiliferous strata of the Burgess Shale Formation. Palaeogeography, Palaeoclimatology, Palaeoecology, 201: 249-268. doi:10.1016/ S0031-0182(03)00612-06

Price, G.D., Gröcke, D.R. (2002): Strontium isotope stratigraphy and oxygen- and carbon isotope variation during the Middle JurassicEarly Cretaceous of the Fackland Plateau, south Atlantic. Palaeogeography, Palaeoclimatology, Palaeoecology, 183: 209-222. doi:10.1016/S0031-0182(01)00486-2

Reolid M. (2008): Taphonomic features of Lenticulina as a tool for pa- 
leoenvironmental interpretation of midshelf deposits of the Upper Jurassic (Prebetic Zone, southern Spain). Palaios, 23: 482-494. doi:10.2120/palo.2007.p07-032r

Reolid, M., Rodríguez-Tovar, F.J., Nagy, J., Olóriz, F. (2008a): Benthic foraminiferal morphogroups of mid to outer shelf environments of the Late Jurassic (Prebetic Zone, southern Spain): Characterization of biofacies and environmental significance. Palaeogeography, Palaeoclimatology, Palaeoecology, 261: 280-299. doi:10.1016/j. palaeo2008.01.021

Reolid, M., Nagy, J., Rodríguez-Tovar, F.J., Olóriz, F. (2008b): Foraminiferal assemblages as palaeoenvironmental bioindicators in Late Jurassic epicontinental platforms: relation with trophic conditions. Acta Palaeontologica Polonica, 53: 705-722. doi:10.4202/ app.2008.0413

Reolid, M., Nagy, J., Rodríguez-Tovar, F.J. (2010): Ecostratigraphic trends of Jurassic agglutinated foraminiferal assemblages as a response to sea-level changes in shelf deposits of Svalbard (Norway). Palaeogeography, Palaeoclimatology, Palaeoecology, 293: 184196. doi:10.1016/j.palaeo.2010.05.019

Reolid, M., Rodríguez-Tovar, F.J., Nagy, J. (2012): Ecological replacement of Valanginian agglutinated foraminifera during a maximum flooding event in the Boreal realm (Spitsbergen). Cretaceous Research, 33: 196-204. doi:10.1016/j.cretres.2011.10.003

Robertson, A.K., Filippelli, G.M. (2008): Paleoproductivity variations in the eastern equatorial Pacific over glacial timescales. American Geophysical Union Fall Meeting 2008, Abstract PP33C-1576.

Rodríguez-Tovar, F.J., Reolid, M., Pardo-Igúzquiza, E. (2010): Planktonic versus benthic foraminifera response to Milankovitch forcing (Late Jurassic, Betic Cordillera): Testing methods for cyclostratigraphic analysis. Facies, 56: 459-470. doi:10.1007/ s10347-010-0216-2

Rutsch, H.J., Mangini, A., Bonani, G., Dittrich-Hannen, B., Kubile, P.W., Suter, M., Segl, M. (1995): ${ }^{10}$ Be and Ba concentrations in western African sediments trace productivity in the past. Earth and Planetary Science Letters, 133: 129-143.

Salas, R., Guimerá, J., Mas, R., Martín-Closas, C., Meléndez, A., Alonso, A. (2001): Evolution of the Mesozoic Central Iberian Rift System and its Cainozoic Inversion (Iberian Chain). In: Cavazza, W., Roberston, A.H.F.R., Ziegler, P. (Eds.). Peri-Tethyan Rift! Wrench Basins and Passive Margins. Museum National d'Histoire Naturelle, Paris, Memoires, 186: 145-185.

Saraswati, P.K. (2002). Growth and habitat of some recent miliolid foraminifera: palaeoecological implications. Current Science, 82, 81-84.

Schlager, W. (1993): Accomodation and supply: a dual control on stratigraphic sequences. Sedimentary Geology, 86: 111-136.

Seilacher, A. (1990): Aberration in bivalve evolution related to photoand chemosymbiosis. Historical Biology, 3: 289-311.

Sen, A.K., Filippelli, G.M., Flores, J.A. (2008): An application of wavelet analysis to palaeoproductivity records from the Southern Ocean. Computers \& Geociences, 35: 1445-1450.

Siebert, C., Nagler, T.F., von Blanckenburg, F., Kramers, J.D. (2003): Molybdenum isotope records as a potential new proxy for paleoceanography. Earth and Planetary Science Letters, 211: 159-171. doi:10.1016/S0012-821X(03)00189-4
Sjoerdsma, P.G., Van der Zwaan, G.J. (1992): Simulating the effect of changing organic flux and oxygen content on the distribution of benthic foraminifera. Marine Micropaleontology, 19: 163-180.

Sun, Y.B., Wu, F., Clemens, S.C., Oppo, D.W. (2008): Processes controlling the geochemical composition of the South China Sea sediments during the last climatic cycle. Chemical Geology, 257: 234-249. doi:10.1016/j.chemgeo.2008.10.002

Thiel, H., Pfannkuche, O., Schriever, G., Lochte, K., Gooday, A.J., Hemleben, C., Mantoura, R.F.C., Patching, J.W., Turley, C.M., Riemann, F. (1990): Phytodetritus on the deep-sea floor in a central oceanic region of the northeast Atlantic Ocean. Biological Oceanography, 6: 203-239.

Tribovillard, N., Algeo, T., Lyons, T., Riboulleau, A. (2006): Trace metals as palaeoredox and palaeoproductivity proxies: an update. Chemical Geology, 232: 12-32. doi:10.1016/j.chemgeo.2006.02.012

Turgeon, S., Brumsack, H.J. (2006): Anoxic vs dysoxic events reflected in sediment geochemistry during the Cenomanian-Turonian Boundary Event (Cretaceous) in the Umbria-Marche basin of central Italy. Chemical Geology, 234: 321-339. doi:10.1016/j.chem. geo.2006.05.008

Turley, C.M. (2000): Bacteria in the cold deep-sea benthic boundary layer and sediment-water interface of the NE Atlantic. FEMS Microbiology Ecology, 33: 89-99.

Tyszka, J. (1994): Response of Middle Jurassic benthic foraminiferal morphogroups to dysoxic/anoxic conditions in the Pieniny Klippen Basin, Polish Carpathians. Palaeogeography, Palaeoecology, Palaeoclimatology, 110: 55-81.

Tyszka, J. (2001): Microfossil assemblages as bathymetric indicators of the Toarcian/Aalenian "Fleckenmergel"-Facies in the Carpathian Pieniny Klippen Belt. Geologica Carpathica, 52, 147-158.

Van der Zwaan, G.J., Jorissen, F.J., de Stigter, H.C. (1990): The depthdependency of planktonic/benthic foraminiferal ratios; constraints and applications. Marine Geology, 95: 1-16.

Van der Zwaan, G.J., Duijnstee, I.A.P., Den Dulk, M., Ernst, S.R., Jannink N.T., Kouwenhoven, T.J. (1999): Benthic foraminifers: proxies or problems? A review of paleoecological concepts. EarthScience Reviews, 46: 213-236.

Van Os, B.J.H., Lourens, L.J., Hilgen, F.J., De Lange, G.J., Beaufort, L. (1994): The formation of Pliocene sapropels and carbonate cycles in the Mediterranean: Diagenesis, dilution, and productivity. Paleoceanography, 9, 601-617.

Villanueva-Gulmerans, P., Canudo, I., 2008. Assemblages of recent benthic oforaminifera from the northeast Gulf of Cadiz. Geogaceta 44, 139-142.

Wenbo, S., Yongbiao, W., Cramer, B.D., Munnecke, A., Zhiming, L., Lipu, F. (2008): Preliminary estimation of palaeoproductivity via TOC and habitat types: which method is more reliable? - A case study on the Ordovician - Silurian transitional black shales of the Upper Yangtze Platform, South China. Journal of China University of Geosciences, 19: 534-548.

Wignall, P.B., Myers, K.J. (1988): Interpreting the benthic oxygen levels in mudrocks: a new approach. Geology, 16: 452-455.

Yilmaz, I.O., Altiner, D., Tekin, U.K., Tuysuz, O., Ocakoglu, F., Acikalin, S. (2010): Cenomanian-Turonian Oceanic Anoxic Event (OAE2) in the Sakarya zone, northwestern Turkey: sedimentological, cyclostratigraphic, and geochemical records. Cretaceous Research, 31, 207-226. doi:10.1016/j.cretres.2009.10.005 